\title{
UJI PATOGENITAS BAKTERI Pseudomonas sp. PADA UDANG VANAME (Litopanaeus vannamei) SEBAGAI KANDIDAT PROBIOTIK
}

\section{Pathogenicity Test of Pseudomonas sp. in White Shrimp (Litopanaeus vannamei) as A Probioitic Candidate}

Ismi M. Habib Pahlawi ${ }^{*}$, Woro Hastuti Satyantini ${ }^{2}$ dan Sudarno ${ }^{2}$

${ }^{1}$ Program Studi Budidaya Perairan, Fakultas Perikanan dan Kelautan Universitas Airlangga, Surabaya

${ }^{2}$ Departemen Manajemen Kesehatan Ikan dan Budidaya Perairan, Fakultas Perikanan dan Kelautan Universitas Airlangga, Surabaya

*habib.pahlawi21@gmail.com

\section{Abstrak}

Penelitian ini bertujuan mengetahui tingkat kematian udang vaname yang diinfeksi bakteri Pseudomonas sp. Bakteri Pseudomonas sp. diisolasi dari sedimen tambak udang. Uji patogenitas menggunakan udang vaname (7-9 gram) yang diinfeksi bakteri Pseudomonas sp. dengan kepadatan $10^{2}, 10^{4}, 10^{6}, 10^{8} \mathrm{sel} / \mathrm{ml}$ secara intramuscular sebanyak $0,1 \mathrm{ml} /$ ekor. Perlakuan kontrol diinfeksi menggunakan $\mathrm{NaCl}$ fisiologis sebanyak $0,1 \mathrm{ml} /$ ekor. Tingkat mortalitas dan gejala klinis diamati setap 6 jam pada 24 jam pertama dan selanjutnya selama 24 jam hingga 10 hari. Hasil yang diperoleh dari uji patogenitas bakteri Pseudomonas sp. pada udang vaname menunjukkan tingkat kematian sebesar 0\% pasca infeksi. Hal ini menunjukkan bahwa bakteri Pseudomonas sp. tidak menyebabkan kematian pada udang vaname. Gambaran gejala klinis yang ditunjukkan berupa hepatopankreas berwarna hijau kehitaman dengan tekstur yang padat dan menunjukkan kenampakan yang sama dengan perlakuan kontrol. Warna tubuh udang vaname setelah diinfeksi bakteri Pseudomonas sp. menunjukkan gambaran yang sama dengan kontrol yaitu berwarna putih transparan. Karapas dan ekor udang vaname setelah diinfeksi menunjukkan tidak adanya kerusakan yang disebabkan oleh infeksi bakteri Pseudomonas sp., gambaran tersebut menunjukkan kenampakan yang sama dengan perlakuan kontrol. Hal ini menunjukkan bahwa bakteri Pseudomonas sp. tidak patogen terhadap udang vaname dan infeksi bakteri Pseudomonas sp. tidak berpengaruh terhadap perubahan morfologi makroskopis dan tingkah laku.

Kata kunci: Patogenitas, Gejala klinis, Pseudomonas sp., Udang vaname, Kematian

\section{Abstract}

This research aims to determine the mortality of vannamei shrimp infected by Pseudomonas sp. bacteria isolated from sediment of shrimp pond. Pathogenicity test was by using vannamei shrimp (7-9 grams) with a density of $10^{2}, 10^{4}, 10^{6}, 10^{8}$ cells $/ \mathrm{ml}$ intramuscularly. The control treatment was infected by using a physiological $\mathrm{NaCl}$ of $0.1 \mathrm{ml}$. The rate of mortality and clinical symptoms were observed for the first of 6 hours for 10 days. The results from the pathogenic test of Pseudomonas sp. in vannamei showed that $0 \%$ post infection of mortality rate. This was indicating that the Pseudomonas sp. bacteria did not cause death in vannamei shrimp. The clinical symptoms showed in the form of blackish-green hepatopancreas with a dense texture. That clinical symptom had the same appearance as the control treatment. The color of vannamei body showed a white color and so with the control treatment. Carapace and tail showed no damage to treatment and control treatment. This indicated that the bacteria Pseudomonas sp. did not cause death to vannamei shrimp and bacterial infections. Pseudomonas sp. did not affect morphological changes in macroscopic and behavior.

Keywords : Pathogenicity, Clinical symptoms, Pseudomonas sp., White shrimp, Mortality

\section{PENDAHULUAN}

Budidaya udang merupakan sektor perikanan yang berperan sebagai penyumbang devisa non-migas yang besar bagi negara (Budiardi et al., 2013). Pada budidaya udang vaname, lingkungan merupakan faktor yang mempengaruhi kelangsungan hidup udang. Pengelolaan lingkungan merupakan salah satu upaya untuk mengatasi serangan penyakit pada budidaya udang vaname. Alternatif yang yang dapat dilakukan dengan menggunakan bakteri agen biokontrol. Bakteri ini bisa didapat dari lingkungan budidaya udang yang memiliki kesesuaian habitat dengan udang vaname. Pseudomonas sp., Pseudomonas fluoresens, dan Pseudoalteromonas haloplanktis merupakan 
mikroorganisme yang diketahui dapat mencegah penyakit pada ikan dan udang (Kamei dan Isnansetyo, 2003; Verschuere et al., 2000).

Bakteri Pseudomonas sp. merupakan bakteri Gram negatif yang mampu menghasilkan senyawa bakteriosin dan senyawa antibiotik untuk menghambat dan menekan bakteri patogen (Spanggaard et al., 2001; Kamei dan Isnansetyo, 2003). Pseudomonas sp. juga mampu menghasilkan enzim kitinase. Enzim kitinase bekerja sebagai katalisator pada proses penguraian polimer kitin pada lapisan pelindung tubuh ikan menjadi unit monomer yang lebih sederhana (Mangunwardoyo et al., 2009). Selain itu bakteri Pseudomonas sp. mampu mempro-duksi beberapa enzim seperti protease, amilase, lipase dan selulase yang dapat mengurai protein, karbohidrat dan lemak menjadi senyawa yang lebih sederhana, sehingga diharapkan bakteri Pseudomonas sp. dapat dikembangkan sebagai bakteri kandidat probiotik.

Menurut penelitian Patria (2015) dan Saputra (2015), bakteri Pseudomonas sp. memiliki kemampuan dalam memproduksi enzim ekstraselular maupun kemampuan antagonis terhadap bakteri Vibrio harveyi. Sebelum bakteri Pseudomonas sp. ini dikembangkan sebagai bakteri kandidat probiotik, perlu dilakukan pengujian lanjutan untuk mengetahui apakah bakteri Pseudomonas sp. dapat menyebabkan kematian tinggi atau tidak bila diaplikasikan pada udang vaname melalui uji patogenitas.

\section{METODOLOGI}

\section{Waktu dan Tempat}

Penelitian ini dilakukan di Tropical

Disease Center (TDC) Unversitas Airlangga. Pemeriksaan patogenitas bakteri Pseudomonas sp. dilakukan di Laboratorium Fakultas Perikanan dan Kelautan (FPK), Universitas Airlangga Surabaya pada bulan April-Juni 2017.

\section{Materi Penelitian}

Peralatan yang digunakan pada penelitian ini antara lain 20 akuarium berukuran $50 \times 35 \times 40 \mathrm{~cm}^{3}$, aerator, 20 batu aerasi, 20 buah selang aerator, dua bak tandon, cawan petri, tabung reaksi, microtube, micropipet, rak tabung reaksi, erlenmeyer, rak microtube, jarum ose, bunsen, spuit ukuran $1 \mathrm{ml}$, hand glove, masker, kertas label, $\mathrm{pH}$ meter, wadah pakan, baskom, timbangan analitik, refraktometer, termometer, DO meter, inkubator, spektrofotometer, vortex, autoclave, kulkas steril, kapas, aluminium foil dan plastik wrap.

Bahan yang digunakan pada penelitian ini yaitu 200 ekor udang vaname dengan berat $7-9$ gram, isolat murni bakteri Pseudomonas sp. koleksi FPK Unair, TSA (Tryptone Soy Agar), TSB (Tryptone Soy Broth), larutan $\mathrm{NaCl}$ Fisiologis, $\mathrm{NaCL}$, standar Mc Farland, akuades, air laut steril, alkohol, klorin, Natrium Thiosulfat, pelet udang, dan es batu.

\section{Rancangan Penelitian}

Isolat bakteri Pseudomonas sp. dengan kepadatan $10^{2}, 10^{4}, 10^{6}$, dan $10^{8}$ $\mathrm{sel} / \mathrm{ml}$ serta larutan $\mathrm{NaCl}$ fisiologis diinjeksikan sebanyak $0,1 \mathrm{ml}$ pada udang vaname.

\section{Prosedur Kerja \\ Kultur Isolat Bakteri Pseudomonas sp.}

Media yang digunakan untuk kultur bakteri Pseudomonas sp. adalah TSA. Pembuatan media dilakukan dengan melarutkan media TSA pada erlenmeyer sebanyak $40 \mathrm{~g} / \mathrm{L}$ akuades sesuai petunjuk dan ditambahkan $\mathrm{NaCl} 15 \mathrm{~g} / \mathrm{l}$. Setelah itu media TSA disterilisasi dengan menggunakan autoclave. Media TSA yang sudah disterilisasi dituangkan pada cawan petri dan ditunggu hingga dingin dan mengeras.

Isolat Pseudomonas sp. kemudian diinokulasikan di media. Inokulasi bakteri menggunakan metode gores atau streak. Selanjutnya inokulum bakteri disimpan di inkubator pada suhu $30^{\circ} \mathrm{C}$ selama 24 jam. Bakteri yang tumbuh selanjutnya diinokulasikan pada media TSB sebanyak satu ose. 
Bakteri yang tumbuh ditandai dengan perubahan media TSB menjadi lebih keruh, kemudian di panen dengan cara di centrifuge pada kecepatan $5.400 \mathrm{rpm}$ selama 5 menit.

Selanjutnya supernatan dibuang dan ditambahkan larutan $\mathrm{NaCl}$ fisiologis kemudian diukur menggunakan spektrofotometer pada panjang gelombang $550 \mathrm{~nm}$ untuk mengetahui pertumbuhan atau kepadatan sel bakteri. Kepadatan bakteri yang diperlukan sesuai dengan perlakuan diperoleh dengan cara pengenceran (Chau et al., 2011) dari jumlah kepadatan bakteri yang terukur sebelumnya pada spektrofotometer.

\section{Persiapan Udang Uji}

Udang vaname didatangkan dari tambak semi intensif di Instalasi Budidaya Air Payau Lamongan, Lamongan yang berukuran rata-rata 7-9 gram, diaklimatisasi selama 5-7 hari. Udang vaname dipelihara di dalam akuarium $\left(50 \times 35 \times 40 \mathrm{~cm}^{3}\right)$ dengan kepadatan 10 ekor/akuarium dengan volume 35 liter dan setara sekitar 300 ekor $/ \mathrm{m}^{3}$ (Wasielesky et al., 2006). Selama budidaya, udang diberi pakan berupa pakan udang komersial.

\section{Uji Patogenitas Pada Udang Vaname}

Udang vaname terlebih dahulu dibius menggunakan suhu rendah. Teknik injeksi bakteri pada udang vaname secara intramuscular pada abdomen segmen ketiga (Chau et al., 2011).

Volume injeksi yang digunakan adalah $0,1 \mathrm{ml} /$ ekor menggunakan spuit berukuran $1 \mathrm{ml}$. Pemeliharaan udang vaname dilakukan selama 10 hari dan diberi pakan pelet komersial. Penga-matan kematian dan gejala klinis dicatat setiap enam jam sekali pada 24 jam pertama, selanjutnya setiap 24 jam sekali hingga hari ke-10 (akhir penelitian).

Perhitungan Tingkat Mortalitas dan $\mathrm{LD}_{50}$ udang vaname dihitung pada akhir pemeliharaan. Menurut Effendie (1997) tingkat mortalitas udang vaname dapat dihitung dengan persamaan berikut :

$$
\begin{aligned}
& Z=\frac{\mathrm{Mt}}{\mathrm{Mo}} \times 100 \% \\
& \text { Keterangan : } \\
& \mathrm{Z} \quad \text { : Tingkat Mortalitas (\%) } \\
& \mathrm{Mt}: \text { Jumlah udang vaname yang mati (ekor) } \\
& \text { Mo : Jumlah udang vaname yang hidup (ekor) }
\end{aligned}
$$

Nilai LD L0 $_{50}$ didapat menggunakan metode aritmatik Reed dan Muench (1938). Metode ini menggunakan nilai-nilai kumulatif sebagai dasar perhitungan. Nilai kumulatif diperoleh dari kematian udang vaname selama rentan waktu pemeliharaan.

Penentuan LD50 didapat berdasarkan persamaan berikut :

$$
\begin{aligned}
& \text { Selang Proporsi } \\
& =\frac{\text { kematian diatas } 50 \%-50}{\text { kematian diatas } 50 \%-\text { kematian dibawah } 50 \%} \\
& \text { Sehingga LD50 didapat dari } \\
& \text { persamaan berikut: }
\end{aligned}
$$$$
\text { LD50 = Log Konsentrasi dibawah 50\% + }
$$
Selang Proporsi

\section{Analisis Data}

Data hasil uji patogenitas bakteri Pseudomonas sp. pada udang vaname (Litopanaeus vannamei) yang diperoleh pada penelitian ini berupa data kuantitatif dan kualitatif. Data tersebut dianalisis secara deskriptif dan disajikan secara naratif dengan tabel dan gambar.

\section{HASIL DAN PEMBAHASAN}

Dari hasil penelitian uji patogenitas didapatkan data kematian udang vaname yang diinfeksi bakteri Pseudomonas sp. $10^{2}$ - $10^{8} \mathrm{sel} / \mathrm{ml}$ sebesar 0\%. Data kematian dapat dilihat pada Tabel 1. Pada penelitian ini udang yang diinfeksi bakteri Pseudomonas sp. tidak menunjukkan adanya kematian di semua perlakuan hingga akhir pemeliharaan. Kondisi tersebut diduga karena produk ekstraseluler yang dikeluarkan oleh bakteri Pseudomonas sp. tidak sampai menyebabkan kematian.

Menurut Mangunwardoyo et al. (2009), bakteri Pseudomonas sp. mampu menghasilkan enzim kitinase yang merupa- 
kan katalisator pada proses penguraian polimer kitin pada lapisan pelindung tubuh ikan nila.

Tabel 1. Data kematian udang vadame (Litopenaeus vannamei).

\begin{tabular}{|c|c|c|c|c|c|c|c|c|c|c|c|}
\hline \multirow{2}{*}{ Perlakuan } & \multicolumn{10}{|c|}{ Hari ke- } & \multirow{2}{*}{$\begin{array}{c}\text { Kematian } \\
(\%)\end{array}$} \\
\hline & 1 & 2 & 3 & 4 & 5 & 6 & 7 & 8 & 9 & 10 & \\
\hline $\begin{array}{l}\text { P0 (kontrol Nacl } \\
\text { fisiologis) }\end{array}$ & 0 & 0 & 0 & 0 & 0 & 0 & 0 & 0 & 0 & 0 & 0 \\
\hline $\begin{array}{c}\mathrm{P} 1\left(10^{2} \mathrm{sel} / \mathrm{ml} \text { bakteri }\right. \\
\text { Pseudomonas } \mathrm{sp} .)\end{array}$ & 0 & 0 & 0 & 0 & 0 & 0 & 0 & 0 & 0 & 0 & 0 \\
\hline $\begin{array}{c}\mathrm{P} 2\left(10^{4} \mathrm{sel} / \mathrm{ml} \text { bakteri }\right. \\
\text { Pseudomonas } \mathrm{sp} .)\end{array}$ & 0 & 0 & 0 & 0 & 0 & 0 & 0 & 0 & 0 & 0 & 0 \\
\hline $\begin{array}{l}\text { P3 }\left(10^{6} \mathrm{sel} / \mathrm{ml} \text { bakteri }\right. \\
\text { Pseudomonas } \mathrm{sp} .)\end{array}$ & 0 & 0 & 0 & 0 & 0 & 0 & 0 & 0 & 0 & 0 & 0 \\
\hline $\begin{array}{c}\text { P4 (10 } \mathrm{sel} / \mathrm{ml} \text { bakteri } \\
\text { Pseudomonas } \mathrm{sp} .)\end{array}$ & 0 & 0 & 0 & 0 & 0 & 0 & 0 & 0 & 0 & 0 & 0 \\
\hline
\end{tabular}

Infeksi bakteri Pseudomonas sp. dengan kepadatan mencapai $10^{8} \mathrm{sel} / \mathrm{ml}$ masih mendukung kelangsungan hidup udang vaname. Hal ini menunjukkan bahwa bakteri Pseudomonas sp. tidak termasuk bakteri patogen. Menurut Todar (2002), bakteri patogen adalah bakteri yang mampu menyebabkan sakit hingga kematian pada hewan uji.

Hasil pengamatan gejala klinis udang vaname yang diinfeksi bakteri Pseudomonas sp. dengan dosis $10^{2}, 10^{4}$, $10^{6}$, dan $10^{8} \mathrm{sel} / \mathrm{ml}$ dan perlakuan kontrol menunjukkan bahwa pengamatan dari enam jam pertama sampai hari ke 10 pemeliharaan yaitu kenampakan tingkah laku dan gambaran morfologi makroskopis yang diinfeksi bakteri Pseudomonas sp. dengan dosis $10^{2}, 10^{4}, 10^{6}, 10^{8} \mathrm{sel} / \mathrm{ml}$ maupun kontrol ( $\mathrm{NaCl}$ fisiologis) pada enam jam pertama sampai jam ke 24 menunjukkan pergerakan udang berenang pasif di dasar.

Pengamatan aktifitas berenang udang vaname Pada pengamatan hari ke dua sampai hari ke 10 udang vaname yang diinfeksi bakteri Pseudomonas sp. dengan dosis $\quad 10^{2}-10^{8} \mathrm{sel} / \mathrm{ml}$ memperlihatkan keaktifan berenang di kolom air maupun permukaan air. Respon makan udang vaname setelah diinfeksi bakteri Pseudomonas sp. dengan konsentrasi $10^{2}$,
$10^{4}, 10^{6}$, dan $10^{8} \mathrm{sel} / \mathrm{ml}$ maupun kontrol $(\mathrm{NaCl}$ fisiologis) menunjukkan respon makan pasif pada pengamatan enam jam pertama. Udang vaname yang telah diinfeksi bakteri Pseudomonas sp. dengan dosis $10^{2}-10^{8} \mathrm{sel} / \mathrm{ml}$ maupun kontrol mengalami peningkatan respon makan selama pemeliharaan pada hari ke dua hingga hari ke-10.

Gambaran morfologi makroskopis diamati melalui gambaran dari hepatopankreas, warna tubuh, kerusakan karapas dan ekor. Udang vaname setelah diinfeksi bakteri Pseudomonas sp. tidak menunjukkan adanya perubahan pada hepatopankreas. Menurut Soto-Rodriguez et al. (2015), udang vaname yang terinfeksi bakteri patogen akan mengalami gejala klinis berupa hepatopankreas akan berubah warna pada bagian pangkal menjadi kuning hingga keputihan.

Pada penelitian ini udang vaname yang diinfeksi bakteri Pseudomonas sp. dengan kepadatan $10^{2}-10^{8} \mathrm{sel} / \mathrm{ml}$ menunjukkan gambaran hepatopankreas berbentuk utuh dan berwarna hijau kehitaman. Perlakuan infeksi infeksi bakteri Pseudomonas sp. kepadatan $10^{2}-10^{8} \mathrm{sel} / \mathrm{ml}$ menunjukkan gambaran yang sama dengan perlakuan kontrol. Pada bagian tubuh udang vaname tidak menunjukkan adanya perubahan warna tubuh maupun rusaknya 
karapas. Menurut Raja et al. (2015), udang vaname yang terindikasi serangan patogen akan berubah warna antara putih pucat sampai kemerahan dan rusaknya karapas yang berfungsi sebagai pelindung tubuh udang vaname.

Tabel 2. Gambaran morfologi makroskopis udang vaname (Litopanaeus vannamei) setelah diinfeksi bakteri Pseudomonas sp.

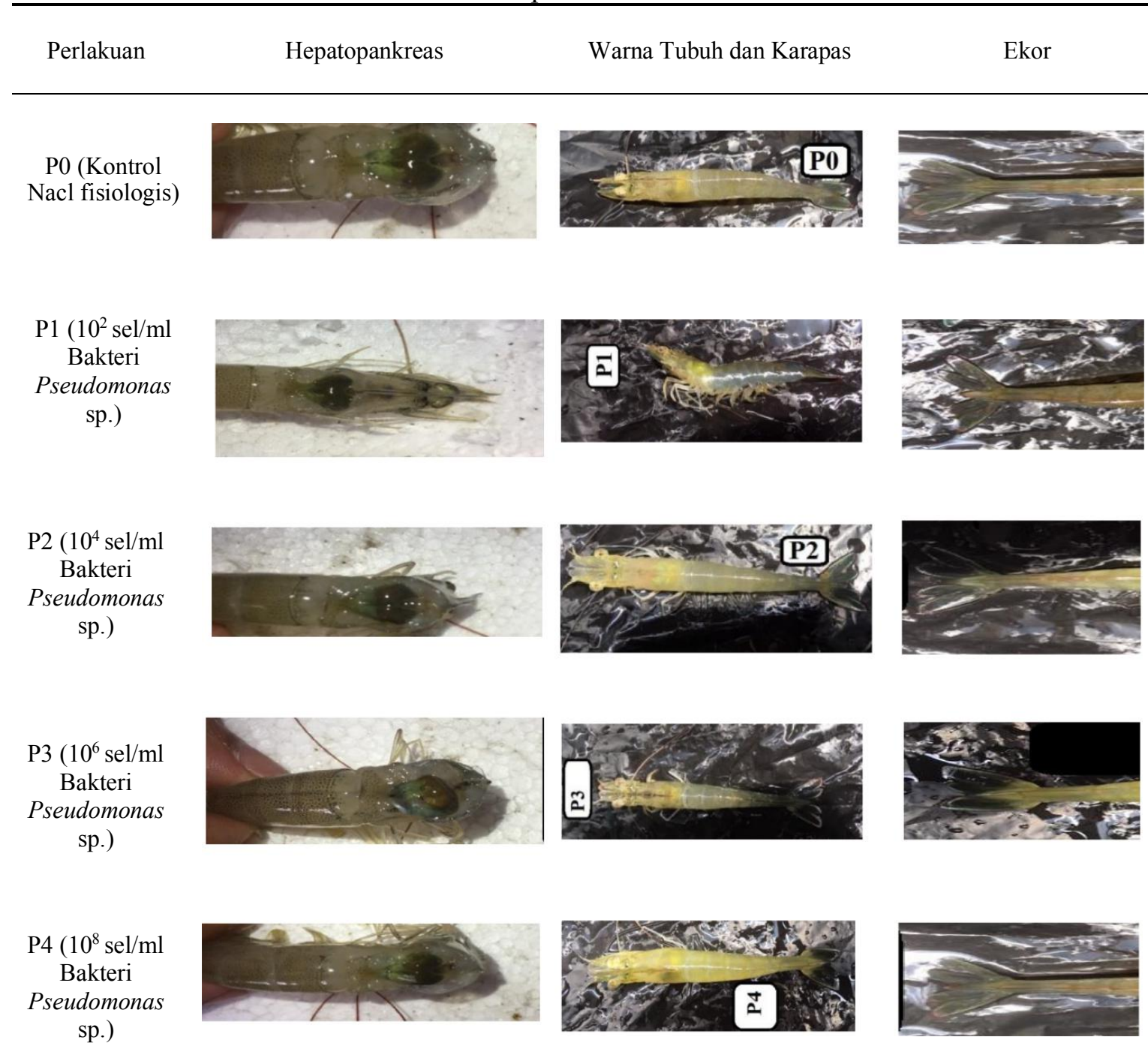

Udang vaname yang diinfeksi bakteri Pseudomonas sp. $10^{2}-10^{8} \mathrm{sel} / \mathrm{ml}$ tidak mengalami perubahan warna tubuh dan menjukkan gambaran yang sama dengan udang vaname pada perlakuan kontrol yaitu tubuh berwarna putih transparan. Udang vaname yang terinfeksi bakteri patogen akan mengalami perubahan warna dan kerontokan pada bagian ekor (Pratama et al., 2014).
Pada pengamatan perubahan warna ekor dan kenampakan ekor udang vaname setelah diinfeksi bakteri Pseudomonas sp. dengan dosis $10^{2}-10^{8} \mathrm{sel} / \mathrm{ml}$ tidak menunjukkan adanya gejala kerontokan maupun perubahan warna pada ekor udang vaname. Pada perlakuan kontrol menunjukkan gambaran yang sama dengan perlakuan udang vaname yang diinfeksi bakteri Pseudomonas sp. menunjukkan ekor berwarna putih transparan dan tidak 
adanya kerusakan pada ekor. Sama dengan gambaran udang pada perlakuan kontrol. Bakteri Pseudomonas sp. memiliki kemampuan menghasilkan enzim kitinase yang dapat mendegradasi zat kitin.

Kemampuan mendegradasi kitin dari bakteri Pseudomonas sp. diduga dapat menyebabkan rusaknya karapas pada tubuh dan kerusakan pada ekor udang vaname. Pada penelitian ini pasca infeksi bakteri Pseudomonas sp. tidak mengakibatkan lepasnya karapas dan kerusakan pada ekor.

Gejala klinis yang diamati pada oleh udang vaname yang diinfeksi bakteri Pseudomonas sp. selama pemeliharaan tidak menunjukkan gejala seperti yang disampaikan oleh Lavilla-Pitogo et al. (2000), bahwa Pseudomonas sp. merupakan jenis bakteri penyebab karapas, kaki jalan, kaki renang dan ekor udang windu mengalami kerontokan. Udang yang terserang bakteri ini mengalami kerusakan terutama pada bagian sirip ekor (uropoda) yang mengakibatkan udang kesulitan berenang. Selain itu bakteri ini juga dapat menyebabkan aktivitas udang lemah, nafsu makan hilang dan rentan stres.

Bakteri Pseudomonas sp. mampu memproduksi enzim bakteriolitik yang dapat menguraikan suatu senyawa menjadi lebih sederhana. Mekanisme yang mampu menyebabkan kematian pada hewan uji dari bakteri Pseudomonas sp. dengan menghasilkan ekstraselullar produk yaitu enzim kitinase. Enzim kitinase adalah enzim yang mampu menghidrolisis kitin menjadi monomer N-asetil-glukosamin (Herdyastuti et al., 2009). Enzim ini yang diduga akan mendegradasi zat kitin yang ada pada karapas maupun ekor udang. Menurut Hardi et al. (2014), bakteri Pseudomonas sp. mampu memproduksi ekstraselullar produk dengan menunjukkan gejala seperti sirip gripis, pendarahan kulit dan luka pada permukaan tubuh dan sisik lepas pada ikan.

Hal ini menunjukkan bahwa sistem petahanan tubuh udang vaname masih mampu melawan zat asing yang masuk kedalam tubuh. Sehingga udang vaname yang diinfeksi bakteri Pseudomonas sp. tidak menyebabkan kematian tinggi.

\section{KESIMPULAN DAN SARAN Kesimpulan}

Kesimpulan dari penelitian ini adalah bakteri Pseudomonas sp. tidak mengakibatkan kematian pada udang vaname (Liptopenaeus vannamei). Infeksi bakteri Pseudomonas sp. melalui penyuntikan secara intraperitoneal hingga dosis $10^{8}$ $\mathrm{sel} / \mathrm{ml}$ tidak berpengaruh terhadap tingkah laku dan perubahan morfologi udang vaname (Liptopenaeus vannamei), sehingga dapat dikatakan bakteri Pseudomonas sp. tidak patogen.

\section{Saran}

Saran yang dapat diberikan pada penelitian ini diharapkan adanya penelitian lanjutan mengenai pengembangan bakteri Pseudomonas sp. sebagai agen probiotik.

\section{DAFTAR PUSTAKA}

Budiardi, T., Muzaki A. dan Utomo, N.B.P., 2013. Produksi Udang Vaname (Litopenaeus vannamei) Di Tambak Biocrete Dengan Padat Penebaran Berbeda. Jurnal Akuakultur Indonesia, 4 (2) :109113.

Chau, N.T.T., Hieu, N.X., Thuan, L.T.N., Matsumoto, M. and Miyajima, 2011. Identification and characterization of Pseudomonas sp. P9 antagonistic to pathogenic Vibrio spp. isolated from shrimp culture pond in Thua Thien Hue-Viet Nam, J. Fac. Agr., Kyushu Univ, 56 (1) :23-31.

Effendie, M.I., 1997. Biologi Perikanan. Yayasan Pustaka Nusatama. Yogyakarta. hal. 130.

Hardi, E. H., Catur, A.P. dan Gina, S., 2014. Toksisitas Produk Ekstraseluler dan Intraseluler Bakteri Pseudomonas sp. pada Ikan Nila (Oreochromis niloticus). Jurnal Veteriner, 15 (3) : 312-322.

Herdyastuti, N., Raharjo, J.T., Mudasir dan Matsjeh, S., 2009. Kitinase dan 
Mikroorganisme Kitinolitik: Isolasi, Karakterisasi dan Manfaatnya. Indo $J$ Chem 9 (1):37-38,40.

Kamei, Y. and Isnansetyo, A., 2003. Lysis of methicillin resistant Staphylococcus aureus by 2,4diacetylphloroglucinol produced by Pseudomonas sp. AMSN isolated from a marine alga. Int. J. Antimicrob. Agents. 21: 71-74.

Lavilla-Pitogo, C.R., Lio Po, G.D., CruzLacierda, E.R., Alapide-Tendencia, E.V. and De la Peña, L.D., 2000. Diseases of penaeid shrimps in the Philippines. Aquaculture Extension Manual, 16 (2) :19-21.

Mangunwardoyo, W., Ratih, I. dan Etty, R., 2009. Aktivitas Kitinase, Lesitinase dan Hemolisin Isolat dari Bakteri Ikan Nila (Oreochromis niloticus Lin.) Yang Dikultur Dalam Keramba Jaring Apung Waduk Jatiluhur, Purwakarta. J. Ris. Akuakutur, 4 (2) :257-265.

Patria, M.W., 2015. Isolasi, Seleksi dan Identifikasi Bakteri Penghasil Enzim Protease, Lipase dan Amilase Dari Saluran Pencernaan Udang Vaname (Litopenaeus vannamei) Asal Tambak Tradisional. Skripsi. Universitas Airlangga. Surabaya. hal. 36.

Pratama, N.P. Slamet, B.P. dan Sarjito, 2014. Pemanfaatan Ekstrak Daun Binahong (Anredera cordifolia) Untuk Penanggulangan Penyakit Bakteri (Vibrio harveyi) Pada Udang Windu. Journal of Aquaculture Management and Technology, 3 (4) :281-288.

Raja, K., Gopalakrishnan, A., Singh, R. and Vijayakumar, R., 2015. Loose Shell Syndrome (LSS) in Litopenaeus vannamei grow-out Ponds and its Effect on Growth and Production. Fish Aquac J. 6 (1):151.

Reed, L.J. and Muench, H., 1938. A simple method of estimating fifty percent endpotants. The American Journal of Hygiene, 27: 493-497.
Saputra, S.D., 2015. Uji Antagonis Isolat Bakteri Asal Sedimen Tambak Intensif dan Tradisional Udang Vaname (Litopenaeus vannamei) Terhadap Vibrio harveyi Penyebab Penyakit Vibriosis. Skripsi. Universitas Airlangga. Surabaya. hal. 40.

Spanggaard, B., Huber, I., Nielsen, J., Sick, E., Pipper, C., Martinussen, T., Slierendrecht, W. and Gram, L., 2001. Potential against vibriosis of the indigenous microflora of rainbow trout. Environ. Microbiol. 3, 755765.

Soto-Rodriguez, S.A., Gomez-Gil, B., Lozano-Olivera, R., BetancourtLozana, M. and MoralesCovarrubias, M.S., 2015. Field and Experimental Evidence of Vibrio parahaemolyticus as The Causative Agent of Acute Hepatopancreatic Necrosis Disease of Culture Shrimp (Litopenaeus vannamei) in Northwestern Mexico. Appl. Environ. Microbiol. 81. pp. 1-11.

Todar, K., 2002. Mechanisms of Bacterial Pathogenicity Endotoxins. Todar Online Textbook of Bacteriology. University of Wisconsin-Madison Departement of Bacteriology.

Verschuere, L., Rombout, G., Sorgeloos, P. and Verstraete, W., 2000. Probiotics Bacteria As Biocontrol Agents in Aquaculture. App. Environ. Microbiol. 64 (3) :655-671.

Wasielesky, W. Jr., Atwood, H., Stokes, A. and Browdy, C.L., 2006. Effect of Natural Production in A Zero Exchange Suspended Microbial Floc Based Super-Intensive Culture System for White Shrimp Litopenaeus vannamei. Aquaculture. 258 (4) :396-403.

Diterima/submitted:23 Mei 2019

Disetujui/accepted: 11 Juni 2019 